\title{
Paradigmatic Reverse in Legal Policy of the Notion of Deliberative Democracy from People's Consultative Assembly (Majelis Permusyawaratan Rakyat) to Village (A Preliminary Study)
}

\author{
Inna Junaenah*
}

\begin{abstract}
This article aims to assert that some regulatory mechanisms, such as the appointment of members of and the voting for decision in both Indonesia People's Deliberative Assembly (MPR) and village flows in a formalizing pattern from the top governmental body of the central, to the regional, and to the ends at the bottom level, the village. This also applies the procedural aspects of the democratic system where the organizational body is made as formal, uniform, and permanent in structure (despite the periods). This somehow seems contradictory with the notion of deliberative democracy (Demokrasi Permusyawaratan) once upheld by the founding fathers of Indonesia. However, the vague understanding surrounding the notion of deliberative democracy necessitates a closer study for a more comprehensive overview, which should also be conducted for better comprehension on the concept of democracy adopted by the MPR. This article serves only as a preliminary study to prelude a more in-depth study. The derivation of legal policy in this article has the purpose of identifying the political direction towards which the village democracy was taken. This article highlights a paradigmatic shift in the legal policy change of the democratic pattern from the village to the MPR, then later from the MPR to the village.
\end{abstract}

Keywords: Deliberation, deliberative democracy, legal policy, MPR, village.

\section{Arus Balik Politik Hukum Gagasan Demokrasi Permusyawaratan dari Majelis Permusyawaratan Rakyat ke Pemerintahan Desa (Suatu Kajian Awal)}

\begin{abstract}
Abstrak
Pada tulisan ini hendak dikemukakan bahwa berbagai pengaturan, misalnya mengenai pengambilan keanggotaan dan putusan MPR serta kelembagaan desa, menampakkan pola imitasi dari kelembagaan di pusat, daerah, maupun desa. Begitu pula mengenai tata cara kehidupan berdemokrasi. Dari kelembagaan demokrasi, badan representasinya dibuat secara formal, seragam, dan permanen (walaupun terdapat periodisasi). Hal ini tampak kontradiktif dengan konsep demokrasi permusyawaratan yang diusung oleh para founding fathers ketika Indonesia berdiri. Namun demikian, pemahaman mengenai demokrasi permusyawaratan itu sendiri masih harus digali agar lebih tergambar secara komprehensif. Begitu pula mengenai konsep berdemokrasi dalam kelembagaan MPR. Tulisan ini merupakan kajian awal sebagai pengantar untuk kajian yang lebih mendalam. Alasan hal ini

PADJADJARAN Jurnal IImu Hukum Volume 2 Nomor 3 Tahun 2015 [ISSN 2460-1543][e-ISSN 2442-9325]

* Lecturer at Faculty of Law Universitas Padjadjaran, Jalan Dipati Ukur No. 35, Bandung, inna_padjadjaran@yahoo. co.id, S.H., (Universitas Padjadjaran), M.H. (Universitas Padjadjaran).
\end{abstract}


ditarik sebagai sebuah politik hukum adalah untuk melihat apabila terdapat desain arah kebijakan terhadap entitas desa untuk dapat melaksanakan kehidupan demokrasi. Tulisan ini menunjukkan perubahan politik hukum pola berdemokrasi dari pemerintahan desa ke MPR menjadi dari MPR ke pemerintahan desa.

Kata kunci: Musyawarah, demokrasi permusyawaratan, politik hukum, MPR, desa.

\section{A. Introduction}

Bagir Manan notes that the preference of republic governmental form by the time of the establishment of Indonesia was more inspired by the life of traditional village than the monarchy system adopted by the reigning kingdoms of that time. In one of his book, he wrote:

"Village government and other indigenous governmental units that are similar to village were conceptually republic in nature because the head of the village (pasirah) came from and was elected by the village itself instead of inheriting the title through a noble lineage. As a matter of fact, the government was performed through deliberative discussion (musyawarah) either directly between all the residents or indirectly through mediation of the village elders. Based on such property, the governmental principles of the village government became a sort of model for the founding fathers to formulate the governmental system of Indonesia, which include among others the deliberative, electoral, cooperative, and collective principles. It is important to note that it was not the government of the ancient Indonesian kingdoms that was utilized as the model. The kingdoms adopted a feudalistic system, which made it unsuitable for the aims of Indonesian independence that bases itself upon the foundation of public supremacy or democracy."1

It is also recognized by the elucidation of the pre-amended version of the 1945 Constitution of Indonesia (Undang-Undang Dasar 1945) which indicates, "in the territory of Indonesia, there are about 250 zelfbesturendelandchappen and volksgemeenschappen, locally known as desa in Java and Bali, negeri in Minangkabau, dusun and marga in Palembang, and numerous other local terms. All these territories have an original structure that makes it proper to identify them as special regions". There is a system in all these forms of village that puts emphasis on democratic decision making. The democratic pattern of this system somehow reaffirmed Mohammad Hatta's thought on village democracy. In the new Village Law (Undang-Undang Nomor 6 Tahun 2014), village, traditional village, or other forms of them formally regarded as, "a legal community unit occupying a bordered

1 Bagir Manan, Lembaga Kepresidenan, Cetakan ke-2, Yogyakarta: FH UII Press, 2003, page 4. 
territory with an authority to regulate and maintain their own interest and government based on local initiative, rights of origin, and/or traditional rights recognized and respected by the system of the Republic of Indonesia". ${ }^{2}$ Underlining this definition, this article seeks to clarify that 'village' refers to a legal community unit, recognized either under the local term of desa (village), or under the other terms.

Values and patterns that develop in the village inspired the founding fathers to formulate them into a governmental body later known as MPR. The challenge laid in choosing which model of village is most suitably used as a reference. In answering that, this article uses sample from models of village that have been made into secondary data, such as the village models in Minang and Makassar.

In deriving the application of concept from village to the MPR, it becomes the focus of this article instead of other bodies such as the People's Representative Council (DPR) or Regional Representative Council (DPD). The reason being, in the original draft of the 1945 Constitution there was yet a governmental body with the format of the DPD. The DPR was also not selected since it was one of the components of the MPR. Another reason was that MPR was the only unique and distinct governmental body formulated by the 1945 Constitution, the only one that was not found in the formal structure of the Dutch East Indies government system. At that time, the constitutional structure was divided as follows:

a. Executive power, consisting of opperbestuur (highest government) according to Grondwet Article 62, and Algemene Bestuur (general government) administered by the Gouverneur Generaal (according to Indische Staatsregeling);

b. Legislative power, consisting of volksraad (representatives), according to Nederlands Staatsblaad of 1916 No. 535 and Indische Staatsblad of 1917 No. 117;

c. Raad van Nederlands Indie (Grand Council of Netherlands Indies), Article 7 of Indische Staasregeling;

d. Hooggerechtshof (Supreme Court), according to article 147 of Indische Staatsregeling; and

e. Algemene Rekenkamer (Finance Auditor Body), Article 117 of Indische Staatsregeling. ${ }^{3}$

In deriving the pattern of deliberative democracy from the MPR to village, the focus ranges from the MPR, DPR, Regional People's Representative Council (DPRD), regency and municipal DPRD, and village. All of which are assessed in regard to the governmental laws that specifically regulate them, as well as other related rules.

\footnotetext{
2 Article 1 Number 1 Law Number 6 of 2014 concerning Village (Village Law).

3 RM A.B. Kusuma, Lahirnya Undang-Undang Dasar 1945, Revised Edition, Jakarta: Badan Penerbit Fakultas Hukum Universitas Indonesia, 2009, page 72-75.
} 
These governmental bodies embody the implementation of the fourth principle (sila) of the Pancasila (five basic principles-which encompasses representation, office filling, and decision making factors).

The stipulations make the impression that there is formalized pattern from the central governmental body, to the regional, and to the village. This is also the case with the democratic procedurals, where the democratic body is structured in a formal, uniform, and permanent state (despite periodization). This is contradictory with the notion of deliberative democracy upheld by the founding fathers during the establishment of Indonesia which demanded for a unique and particular characteristic of Indonesian democracy.

Why is it derived as legal policy? The reason behind it is to extract a pattern that explains the political direction towards which the village democracy is heading; namely, what kind of legal policy is reflected in the formalization of village governmental bodies? There are several questions addressed by this article: 1) how is the notion of village Deliberative democracy proposed by the founding fathers integrated into the democratic procedural of Indonesian governmental bodies?; 2) Is there any paradigmatic reverse in the legal policy democratic pattern, from village-MPR adoption into MPR-village adoption? However, a comprehensive understanding of deliberative democracy itself is required for better overview; a preliminary study like this one is inadequate to fully explain it. A fuller and better comprehension is also needed on the concept of democracy utilized by the MPR, from its establishment to the stipulation contained in the amendment of the 1945 constitution.

As preliminary study, this article briefly summarizes the philosophies that underline the MPR stipulations in the 1945 Constitution, both prior and after its amendment. In complying its materials, an overview on the normative stipulation of representation, position filling, and decision voting in several governmental institutions such as the MPR, DPR, DPD, DPRD, and village will be provided as well. Village in this article is understood as a legal community unit, which is also a democratic body that inspired the notion of deliberative democracy.

\section{B. The Notion of Village Deliberative Democracy}

The attempt to systemize democracy appears to never reach a singular point. Abu Daud Busroh and Abu Bakar Busroh admit that it is difficult to agree upon a single ultimate formulation where democracy is concerned. This view was based on Bonger's opinion which stated that democracy in general is only a form of procedurals. ${ }^{4}$ At least, the diversity in the notion of democracy can be seen in its division into direct and indirect democracy, formal and material democracy, Models

4 Abu Daud Busroh and Abu Bakar Busroh, Asas-Asas Hukum Tata Negara, Jakarta: Ghalia Indonesia, 1983, page 136. 
of Democracy by David Held, and Pancasila Democracy.

The rise of distinction between direct and indirect democracy originates from the realization of its development that democracy, as a governmental mechanism instrument, is difficult to be directly implemented. Factors such as area, number of residents, and other increasing issues of state contribute to the complication in the implementation of direct democracy, leading to the argument that direct democracy is practically impossible to be applied. ${ }^{5}$ Even so, Abu Daud Busroh and Abu Bakar Busroh refute Rousseau's argument which stated that an ideal democracy does not exist. While it is indeed against the nature for a large number of people to carry out a government, Busroh argues that in general democracy comes in representative form. ${ }^{6}$ Based on it, we came to know the notion of indirect democracy, where the realization of public supremacy is not directly performed, but rather done through representative bodies. ${ }^{7}$ This is mainly referred as representative democracy. ${ }^{8}$ In order to realize public supremacy, the accommodation of public aspirations has to be represented in a representative system. ${ }^{9}$ According to the International Commission of Jurist, a democratic political system is a form of government where the rights to formulate political decision are administered by a state through representatives elected by the public. The representatives are responsible to the public and selected through an open election. ${ }^{10}$ Representative democracy is the best alternative to attain a representative government. ${ }^{11}$

The classification of formal and material democracy is used by Bonger. Further discussion on the issue of indirect democracy by Abu Daud Busroh and Abu Bakar Busroh divides democracy into formal and material democracy. Formal democracy is a form of government running the principle of, "from the people, by the people, and for the people". In such form of democracy, there is no notable distinction except several variations. Meanwhile, material democracy is a democracy that demands achievement of freedom and equality for everyone. There are many fundamental distinctions in material democracy, which in later development labelled as people democracy, basic democracy, guided democracy, and many others. Sri Soemantri asserts that based on its development, material democracy can be grouped into two, the one that runs on freedom and equality, and the one that runs on development in social and economic sectors. ${ }^{12}$

5 Eddy Purnama, Kedaulatan Rakyat, Bandung: Nusamedia, 2007, page 10.

6 Abu Daud Busroh and Abu Bakar Busroh, Op.cit. page 136.

7 Eddy Purnama, Op.cit., page 11.

8 Miriam Budiardjo, Dasar-Dasar Ilmu Politik, Cetakan ke-15 ed., Jakarta: PT. Gramedia Pustaka Utama, 1993, page 61.

9 Eddy Purnama, Op.cit.,page 284.

10 Miriam Budiardjo, Op.cit., page 61.

11 Wolfgang Friedmann, Legal Theory, London: Steven Sons, 1976, page 419.

12 Abu Daud Busroh and Abu Bakar Busroh, Op.cit., page 137. 
The next form of classification was taken from David Held's models of democracy proposed in 2006. The evolution of democracy, according to Held, ranges from classic to modern democracy. In general, Held divides democracy into eleven clusters which are, classic democracy, two types of Republican thinking (protective republicanism and developmental republicanism), two liberal democracy concepts (protective democracy and developmental democracy), Marxist concept (direct democracy and the end of politics), and the modern democracy mentioned before (competitive elitist democracy, pluralism, legal democracy, participatory democracy, and deliberative democracy)..$^{13}$

Nevertheless, there have been several forms of criticism on democracy itself. Quoting Dahl, Yudi Latif asserts that a political system which allows room for contestation and participation among a society pressured by poverty and grows with foolishness can only be categorized as a democracy that materializes in form but hollow in substance. ${ }^{14}$ Quoting Alexis de Tocqueville, Yudi Latif also mentions that democracy is a multidimensional subject which revolves around political, moral sociological, economic, anthropological, and psychological aspects. ${ }^{15}$ Michael Mezey proposes that democracy in its ideal form is impossible to be realized; it is only possible if a decision was made through public participation on a local context of a very specific issue. Mezey's view originates from his evaluation on the relationship between democracy and representation, which he deems as contradictio in terminis. According to him, representation reduces the values of democracy itself. ${ }^{16}$

Another criticism on democracy is P.C. Alexander's writing on the weakness of democracy. According to him, electoral institution, as a basic element in representative government is prone to power abuse that happens behind the curtain of every single general election. ${ }^{17}$ The large number of people and the lack of proper education contribute largely to this weakness. ${ }^{18}$ It is getting worse by the lack of correlation between democracy and market economy. Alexander takes Singapore and South Korea as examples. Both countries have strong economy despite lacking in history and experience of democracy. ${ }^{19}$ Ironically, in his writing, Alexander mentions Indonesia (in 1995) as an example of a state whose governmental system is corrupt and worthless. ${ }^{20}$ Unfortunately, such weakness is

\footnotetext{
13 David Held, Models of Democracy, Third Edition, Cambridge: Polity Press, 2006, page 3.

14 Yudi Latif, Negara Paripurna, Historisitas, Rasinalitas, dan Aktualitas Pancasila, Jakarta: Kompas Gramedia, 2011, page 456-457.

15 lbid., page 457.

16 Michael L. Mezey, Representatives Democracy, Legislators and Their Constituents, Maryland: Rowman \& Littlefield Publishers, Inc., 2008, page 1-2.

17 P.C. Alexander, Perils of Demokrasi, Delhi: So Maiya Publication, 1995, page 6.

18 Ibid.

19 Ibid., page 63.

20 Ibid.
} 
not anticipated by accountability, which according to Alexander is an important element of representative government. ${ }^{21}$ Alexander states that, "Accountability is not to be enforced only at the time of elections, but has to be a continuing feature to govern the relationship between the elected representative and electorate." In reality, the concept of accountability has not been properly developed in democracy, which leads to its vulnerability. ${ }^{22}$

In this kind of reality, Yudi Latif considers that despite any principal similarity, democracy does not bear the same face, since it has to adapt to the context of time and space of the society upon which it resides. It is then understandable that the founding fathers intended to formulate a unique variant of democracy to suit the social context of Indonesia, the Demoracy of Pancasila. According to Yudi Latif, the founding fathers fully realized the risks of political repression and economic exploitation that came along colonialism and capitalism. ${ }^{23}$ Because of that, they realized that the plural social condition of Indonesia required an unified spirit to fight any forms of social inequality. ${ }^{24}$ The legal policy of the notion of deliberative democracy, both in the MPR and in the village, has a certain relation with the views of the founding fathers. Yamin viewed that deliberative discussion is necessary to reach a mutual agreement. It's a conceptual blend between permusyawaratan (deliberation) that originates from Islamic view and mufakat (agreement) as an originally Indonesia concept. ${ }^{25}$

Bagir Manan appreciates the founding fathers who regarded dem5ocracy not only as a political tool, but also as a social, economic, and cultural tool. ${ }^{26}$ Soekarno upheld the principle of politieke-economieschedemocratie, while Bung Hatta introduced social democracy or collectivism as a blend of political and economic democracy. It should be underlined that, "the founding fathers have established Indonesian democracy upon the foundation of deliberative discussion, humanitarianism, equality, and sense of kinship." This model of democracy is expected to suit the nation's cultural characteristic of being a plural society. It stated that, "in deliberative democracy led by wisdom, the legitimacy of democracy is not determined by the amount of vote for a decision, but rather by an inclusive negotiation and dliberative discussion to yield a mutual agreement." ${ }^{27}$ The essence of this deliberative democracy is a political approach that focuses on improving the

\footnotetext{
${ }^{21}$ Ibid., page 4.

22 Ibid.

23 Ibid., page 458 .

24 Ibid.

25 I Gede Pantja Astawa, "Hak Angket dalam Sistem Ketatanegaraan Indonesia Menurut UUD 1945", Tesis Universitas Padjadjaran, Bandung, 1999, page 86.

26 Bagir Manan, Politik Publik Pers, Jakarta: Dewan Pers, 2012, page 31.

27 Yudi Latif, Negara Paripurna, Historisitas, Rasionalitas, dan Aktualitas Pancasila, Jakarta: Kompas Gramedia, 2011, page 458 .
} 
quality of democracy by redressing the characters and forms of political participation, not only dedicated for the good of the few. ${ }^{28} \mathrm{He}$ also mentioned that deliberative democracy prioritizes deliberative discussion of consensus-yielding arguments over voting. Deliberative discussion is believed to promote the quality and acceptability of collective decision. ${ }^{29}$

Another classification of democracy that supports deliberative democracy is the view of Arend Lijphart, which is majoritarian and consensus democracy. In the view of majoritarian democracy, the majority rules while the minority becomes opposition..$^{30}$ This view is a complete opposite to consensus democracy, which is "a democratic regiment that emphasizes consensus instead of opposition, that includes rather than excludes, and that tries to maximize the size of the ruling majority instead of being satisfied with a bare majority." ${ }^{13}$ With such theoretical perspective, Yudi Latif supports the idealist views of the founding fathers in choosing consensus democracy as the most functional model. ${ }^{32}$ According to him, Deliberative democracy aims to get rid of domination of a particular person or group of people, preferring instead a spirit of kinship. This form of democracy not only evades the dictations of the majority, but also avoids the hegemony of minority from the oligarchy of the ruling elites. This was what Soekarno envisioned back then-for democracy to dismiss the models of 'majocracy' or 'minorocracy. ${ }^{133}$

The deliberative democracy has its root in the tradition of village deliberation. ${ }^{34}$ The mechanism of deliberative democracy can be understood by firstly comprehending how a traditional village works. The way of how village works used as an effort of naming on an entity of culture, economy, and politics that have been existed way before the colonialism and will still continue to exist. Furthermore, the concept of a village as a territorial unit occupied by a community with their own cultural equipment defines an autonomous political and economic system. ${ }^{35}$

Several models of village democracy were inspired by the traditional lives in Java, Minang, and Makassar. Firstly, Aidul Fitriciada asserts that village democracy proposed by Hatta refers to the notion of nagari in Minang. Hatta's concept of village democracy was believed to effectively contain an essence of a deliberativebased democracy-wherein lies the ideal notion of a republic. Hatta's proposed concept of democracy was based on Indonesia's indigenous ways of democratic life,

\footnotetext{
${ }^{28}$ Ibid., page 459.

29 Ibid.

${ }^{30}$ Arend Lijphart, Patterns of Democracy, Yale: Yale University Press, 1999, page 31.

31 Ibid., page 33.

32 Ibid., page 462.

33 lbid., page 483.

34 Ibid., page 478.

35 Irine H. Gayatri, "Demokrasi Lokal di Desa", http://interseksi.org/publications/essays/articles/ demokrasi_lokal_di_desa.html, accessed 5 November 2015
} 
which was the village community system itself. He said that the former states of Indonesia were feudal territories ruled by kings or autocrats. ${ }^{36}$ Even so, the system of democracy in the villages developed, grew, and became a living tradition. ${ }^{37}$ This proves that the original Indonesian democracy has survived since its existence as the nation's old incarnation. Conversely, the modern conception of Indonesia is based on other forms of democracy. There were five unique elements of Indonesian village democracy, namely meeting, agreement, cooperation, rights to collectively protest and evacuate from a particular territory, as well as being socially respected. These elements shape a strong pillar of social democracy. ${ }^{38}$

Village democracy serves as proving ground in developing democratic attitude. People have been used to discuss collectively and deliberatively in which they learn how to debate and compromise to yield a mutual agreement. Thus, developing the attitude is necessary for modern democracy. According to Hatta, there is no other form of democracy in the world as in Indonesia. The problem with the form of democracy in the west, he argues, is that the public supremacy is confined in the sphere of politics. Hatta asserts that it is impossible to achieve true public supremacy without allowing supremacy in the economic sphere as well. While the elite make use of their power to conduct corruption, Hatta and his idealism should be an orientation point for all of us. It is not surprising, then, that there is a view that considers democracy as a form of social control on public matters formed on the foundation of political equality. ${ }^{39}$

Secondly, democracy in Java described by Aldul Fitriciada ${ }^{40}$ as a socially autonomous unit that simultaneously worked along the old concentric tradition of the old Indonesian kingdoms. Different from the feudal life in the era of the kingdom, the village political tradition was conducted in democratic and relatively egalitarian fashion, although still somehow affected by the concentric practice of the kingdom. During the $14^{\text {th }}$ and $15^{\text {th }}$ century, village was shown to have a strong autonomy in comparison to the weak influence of the kingdom; this condition would soon change in the $17^{\text {th }}$ and $18^{\text {th }}$ century when the kingdom sent their officials to villages for taxation. The arrival of the ulama as religious ambassadors also served to reinforce village autonomy in balancing the concentric influence of the kingdom.

The decision makers in the village tradition were the elders, apart from the head of village sub-division called lurah. Decisions were made in tiers, starting in the

\footnotetext{
${ }^{36}$ Khalid O. Santosa, (Ed.), Mohammad Hatta: Demokrasi Kita, Pikiran-Pikiran tentang Demokrasi dan Kedaulatan Rakyat, Cetakan Kedua, Bandung: Sega Arsy, 2009, page 115.

37 Ibid.

38 Ibid.

39 Asmara Nababan (Ed.), "Satu Dekade Reformasi: Maju dan Mundurnya Demokrasi di Indonesia", Ringkasan Eksekutif dan Laporan Awal Survei Nasional Kedua Masalah dan Pilihan Demokrasi di Indonesia, DemosLembaga Kajian Demokrasi dan Hak Asasi, 2008.

40 Aidul Fitriciada, Rekonstruksi Tradisi Bernegara dalam UUD 1945, Bantul: Genta Publishing, 2014, page 21-33.
} 
smallest level of family. In a larger scope, the leader is a buyut. Whoever appointed as village head was usually an elder whose term was lifelong. Although village head had the authority to make decision, the execution of his decision would still have to go through deliberative discussion with the other elders. In other words, Javanese village democracy has already reflected a democratic mechanism that included deliberative discussion to yield a mutual agreement. The method of choosing a village head underwent a change by the time Governor General Raffles introduced direct election. He expected that voting in a direct election system would serve the restoration of the people's rights. This method, implemented during the era of the Dutch East Indie, was designed for direct appointment of village head by the public and minimazing the influence of the elders. Aidul Fitricidia demonstrates that Raffles' method somehow broke the long-established tradition of representation.

Thirdly, democracy in Makassar and Bugis ${ }^{41}$ gave influence to the governmental tradition of eastern Indonesia. In Java, the governmental tradition was focused on the concentric kingdom and traditional village. Meanwhile, in Makassar and Bugis, the focus was only on the kingdom. However, since all the kingdoms in this area were Islamic kingdoms as opposed to the Hindu kingdoms in Java, the concentric property vital to the Hindu influence could not be found here. The governmental unit parallels with a village possess autonomy to issue kingdom policies. Moreover, the governmental unit, often called wanoa or bori, was capable of making social contact with the king. Representatives of each unit was collected under a traditional regional body called arungpitu'e and bate salapang. It is unclear from Fitriciada's elaboration whether a definitive or uniform structure was evident in each of the autonomous wanoa.

The classification of representation in a representative body was found in Jimly Asshiddiqqie's work in the "Introduction of Constitutional Law Vol. II". Jimly explains that there are three functions of a branch of legislative authority, namely legislative function, supervisory function, and representative function. Among those three, in institutionalizing the representative function, there are three systems of representation implemented in most democratic states. They are political, territorial, and functional representation system. ${ }^{42}$ Jimly connects the three systems by referring to the institutional body in which they manifest within each democratic state. If there is one representative system adopted in a state, the form and structure of the representative institution tends to be unicameral. However, if two out of three systems were adopted, the representative institution tends to be bicameral. ${ }^{43}$ Jimly elaborates the United States (US) as an example on which

\footnotetext{
41 Ibid.,page 40-51.

42 Jimly Asshiddiqie, Pengantar IImu Hukum Tata Negara Jilid II, Jakarta: Sekretariat Jenderal dan Kepaniteraan Mahkamah Konstitusi Republik Indonesia, 2006, page 32-40.

43 Ibid., page 41.
} 
implementation of political representation system in their House of Representatives, and territorial representation system in their Senate made their representative institution bicameral in structure. This is also the case with the United Kingdom (UK) with their House of Representatives and House of Lords. However, while in the US a member of the Senate is a territorial representative who is not necessarily from any political party, the UK's House of Lords is functional in representation. ${ }^{44}$

Another example is Irish bicameral system which adopts functional and political representation. Members of Sienad leramm are functional representatives of professional or academic circles, while the House of Representatives elected from political parties ${ }^{45} \mathrm{~A}$ very unique aspect, according to Jimly, is that the system adopted in the institutionalization of the MPR before the amendment of the 1945 Constitution actually unified the three systems altogether. In article 2 verse 1 it is stated that:

"The MPR consists of members of the DPR, in addition to the representatives from factions and regions, elected through the regulation of the law."

It is further elaborated that:

"It means that every faction, group, circle, and every region has a representative in the Assembly. Thus, the assembly can really be considered as the manifestation of the people. Factions mentioned in the article refer to institutions like the cooperatives, labor union, and other collective bodies. The regulation is adjustable to the social context of the time. Due to the suggestion to dismiss the cooperatives from the economy, this verse recognizes other economic bodies as factions."

Therefore, around that time, the MPR included every single one of the three functions: the political representation (the DPR), the territorial representation (representatives sent by each region), and functional representation (representatives of each faction). However, Jimly does not elaborate on the relation between each function or their institutional form.

In Article 2 verse (1) of the 1945 Constitution, it is stated that the MPR consists of the DPR, in addition to the representations of regions and factions as instructed by the law. In verse (2), it is stated that the MPR holds a meeting session at least once every five year in the capital of the nation. At verse (3) it is stated that every decision of the MPR is made through voting. Before the composition of the MPR in the preamended 1945 Constitution, it is mentioned that, "Public supremacy is held by a

\footnotetext{
44 Ibid., page 42.

45 Ibid.
} 
body called People's Consultative Assembly, as a manifestation of the entire Indonesian society."

Abu Daud Busroh and Abu Bakar Busroh argue that the term 'manifestation' somehow is ambiguous and could draw different interpretations, among which are:

a. Interpretation defines that MPR is identical or the same with the society; and

b. Interpretation defines MPR as a representative body that reflects the will of the people for containing the representations of each faction and group in the body.

According to Busroh, if the first interpretation were to be adopted, there would be no difference of views between the MPR and the people. However, if the second is to be adopted, the difference between the two could be consolidated. Only if the difference is too great, then it can be concluded that the MPR no longer reflects the will of the people. ${ }^{46}$ In regard to this Busroh expresses his preference for the term 'representation,' instead of 'manifestation.'

During this era, Sri Soemantri captured the MPR as a body responsible with the implementation of public supremacy while questions on how public supremacy manifests through the MPR. According to him, MPR has been positioned as the only governmental body responsible with the implementation of public supremacy. Even so, MPR does not perform political or basic sovereignty, it only performs legal sovereignty, since basic sovereignty only lies in the hands of the people. The manifested form of legal sovereignty is the authority to formulate regulations, which are the 1945 Constitutions and the legally binding provisions of MPR. ${ }^{47}$

Sri Soemantri also highlighted several things regarding the part of, "supremacy only lies in the hands of the people and is implemented fully by the MPR." Firstly, that is according to the 1945 Constitution, supremacy only lies in the hands of the people; secondly, that public supremacy is performed by the MPR; thirdly, that the MPR is a governmental body to fully implement public supremacy. ${ }^{48}$ According to Sri Soemantri, the article does not contain the idea of the transfer of supremacy from the people to the MPR, only that the MPR is the implementer of public supremacy or legal sovereignty. ${ }^{49}$

A.B. Kusuma argues that the formulators of the 1945 Constitution created sort of new governmental form through the establishment of the MPR. The founding fathers got their inspiration from the British supreme body, wherein public supremacy resides. ${ }^{50}$ Only the members of the parliament are elected; it is not the

\footnotetext{
46 Abu Daud Busroh and Abu Bakar Busroh, Op.cit., page 141.

47 Sri Soemantri, "Penerapan Kedaulatan Rakyat dalam Kehidupan Bernegara Berdasarkan Pancasila dan UndangUndang Dasar 1945", in B. Arief Sidharta dkk (Ed.), Butir-Butir Gagasan tentang Hukum dan Pemerintahan yang Layak, Bandung: Citra Aditya Bakti, 1996, page 453.

${ }^{48}$ Sri Soemantri, "Masalah Kedaulatan Rakyat", in Padmo Wahjono (Ed.), Masalah Ketatanegaraan Indonesia Dewasa Ini, Jakarta: Ghalia Indonesia, 1984, page 68.

49 Ibid., page 70-71.

50 RM A.B. Kusuma, Op.cit., page 38.
} 
case with their executive body. The formulators of the 1945 Constitution saw the possibility of dictatorship in the British system if the party of the Minister gains substantive lead in votes. Avoiding that, the founding fathers only sought to use the good aspect of the British system. They also did not wish for the system of the government to change periodically. ${ }^{51}$ In this regard, they adopted the US system of fixed-government. US sovereignty is divided horizontally between executive, legislative, and judicial functions as contained in their constitution.

Based on the above description, deliberative democracy places deliberative discussion as its core instrument. This is the basic principle of consensus democracy. Moreover, deliberative democracy demands representation that is parallel with open participation. Bagir Manan emphasizes in regard of this aspect that there is no democracy without participation. ${ }^{52}$ In the concept of village democracy, such characteristic is expressed through non-formal and dynamic institutions.

\section{The Shift in Legal Policy of Democratic Pattern}

There have been numerous definition of legal policy which came from some scholars such as Teuku Mohammad Radie, Padmo Wahjono, Soedarto, Mahfud M.D., and Satjipto Rahadjo. ${ }^{53}$ All of the definitions poin out the direction towards where the law is built. As an addition, Sutojo Wignyodipuro states that legal policy inspects what changes are necessary in the current legal system to suit the need of the society. ${ }^{54}$ As an emphasis, Abdul Latif and Hasbi Ali underline legal policy as a part of legal theory that assess the change in the current law by selecting and determining legal provisions towards a purpose, as well as the tools and mechanisms required in the attainment of the purpose in order to formulate the change in society into a law as desired. ${ }^{55}$

Bagir Manan also asserts the meaning of 'legal policy' as a legal development politics and a legal engineering politics. He also stated that the essence of legal development is the renewal of law. Others interpret legal development as the formulation of new laws (including the amendment of old laws) and as laws related with development. In regard to renewal, legal policy is a politics for social engineering (quoted from Roscoe Pound). ${ }^{56}$ The legal policy of the notion of deliberative democracy was evident in the formulation of the regulation on MPR, both before and after the amendment of the 1945 Constitution. As elaborated

\footnotetext{
51 Ibid., page 39.

52 Bagir Manan, Politik Publik Pers, Op.cit., page 34.

53 Among those opinions documented in Imam Syaukani, Dasar-Dasar Politik Hukum, Jakarta: Raja Grafindo Persada, 2010, page 18-30.

54 Abdul Latif and Hasbi Ali, Politik Hukum, Jakarta: SinarGrafika, 2010, page 10-11.

55 Ibid., page 10-11.

56 Bagir Manan, "Politik Hukum untuk Otonomi Daerah", Paper presented in Kuliah Umum Pascasarjana FH Unsyiah, Banda Aceh, 26 September 2013, page 1-2.
} 
above, it is clear that the legal policy after the establishment of the MPR was to nationalize democratic life in the village, despite not the smallest details. This political direction concerned among all the matters is about who were eligible to be members of the MPR, how the positions in the MPR were filled, and what the mechanism of decision making was. The democratic pattern was derived from the village, so that the implementation of government would still be familiar to both the government and the people.

With or without a well-planned design, the legal policy underwent a countershift in paradigm. What had been lacking from the practices of MPR before the amendment of the 1945 Constitution became institutionalized and implemented to various democratic bodies on multiple levels. This was evident in the regulations of the MPR. Based on Article 2 of the 1945 Constitution it is set out that it is now consists of only DPR and DPD, whose members are elected in the general election. ${ }^{57}$ It means that the membership of the current MPR has eliminated the functionalbase representation previously manifested in faction or group representatives. The difficulty to point out worthy representatives becomes an issue to be addressed in filling the vacant chairs of the MPR.

In the MPR, all decisions were made through voting, as regulated by Article 2 verse (3) of the 1945 Constitution which has not undergone change, stating, "Every decision of the MPR is made through voting." Bagir Manan argues that during the New Order, decision making was not made through voting, ${ }^{58}$ but through unanimous agreement. Voting, he argues, opposes every cultural principle that went into the founding of the nation. Ever since then, almost every important issue has been decided through voting. ${ }^{59}$

Moreover, Bagir Manan clarifies the matter pertaining of whether calling for voting and deliberative discussions are polar oppositions. Bagir Manan emphasizes that what is important in democracy is that every decision is made through peaceful reconciliation and discussion. If there are differing viewpoints, then it is possible to conduct voting. Thus, deliberative discussion is the instrument of decision making, either directly results a mutual agreement or a voting. ${ }^{60} \mathrm{He}$ reaffirms that voting needs not to be polarized against mutual agreement, as long as it is conducted with civility, honesty, and transparency only be done by the agreement of all the participants of the deliberative discussion. ${ }^{61}$ Nevertheless, the stipulation of Article 2 verse (3) is induced a misleading interpretation that deliberative discussion to yield a mutual agreement can just be dropped altogether. The priority then

\footnotetext{
57 Article 2 verse (1) the Amandement of 1945 Constitution.

58 Bagir Manan, DPR, DPR, dan MPR dalam UUD 1945 Baru, Yogyakarta: FH UII Press, 2003, page 77.

59 Ibid.

60 Ibid., page 78.

61 lbid., page 79.
} 
becomes the obsession over votes, disregarding prior deliberative discussion.

Another notable aspect in the nature of collective agreement during the New Order had a dictatorship tendency. This was evident in the appointment of only a single presidential candidate, a decision agreed upon by the MPR. In such context, there was no room for other candidates. Such phenomenon was made worse by the cooptation of the New Order regime towards the MPR. The element of DPR as a political representation was under the influence of the president; it was also the case with the appointment of regional representatives that only consisted of members who are hard line loyalists of the ruling regime. Even the functional representation of the factions became questionable. For that reason, it is difficult to materialize the principle of yielding a decision through an open, equal, and peaceful reconciliation between the members of the MPR.

This phenomenon implicates even to the post-reform era, where the overdependence on voting often makes deliberative discussion process abandoned in place of objective argumentation. Even when a dialog is conducted, it is only done as a formality and rarely conducted in polite manners. This is especially true in the formulation of the Head of Region Bill. The main issue of the debate only revolves around whether the heads of the regions are to be directly elected by the people or representatively through the DPRD. The argument only prioritizes pragmatic excuses-pitting cost efficiency against a view that abolishing direct election of heads of regions which would serve as a step back for Indonesian democracy. It never leaves the debate of what function should a governor, regent, or mayor occupy. As a result, the Law Concerning Regional Government has to depend largely on the Law Concerning Regional Election. The slightest revision on the Law Concerning Regional Election would result in a revision in the Law Concerning Regional Government as well. This is getting worse when there is a dealing transaction between the law maker and the stake holder. Such condition makes it difficult to materialize the principles of openness and honesty through democratic discussions.

On a local level, the democratic pattern of the MPR also reflected in the institutionalization of the DPRD. Before the amendment, it was elaborated in Article 18 of the 1945 Constitution that, "for autonomous regions, there will be a regional representative body". Such situation made the existence of regional representative body to conform only to the interest of decentralization. Asep Warlan Yusuf stated that deliberative discussion should reflect a democratic approach that is identical with wisdom and should be performed peacefully. ${ }^{62}$ Furthermore, promoting deliberative discussion as a directly performed democratic element shall facilitate

\footnotetext{
62 Asep Warlan Yusuf, "Sendi Penyelenggaraan Pemerintahan di Daerah dalam Kerangka Perwujudan Otonomi yang Nyata, Dinamis, Serasi, dan Bertanggung Jawab", in B. Arief Sidharta dkk (Ed.), Butir-Butir Gagasan tentang Hukum dan Pemerintahan yang Layak, Bandung: Citra Aditya Bakti, 1996, page 14.
} 
people in speaking up their aspiration to decide various aspects in the development of their regions. ${ }^{63}$ The first reason is that there is no sufficient reason to state that the composition of the DPRD to be symmetrical to DPR, for which the reason is political representation. ${ }^{64}$ The regulation instructs that the DPRD consists of political party members elected in the general election, but there is no stipulation or concept that serves as the basis for a structural connection between DPR and DPRD. Secondly, Law Number 23 of 2014 Concerning Regional Government contained better formulation on how decision is made. There are two steps, the primary step is that decision making process always includes deliberative discussion to reach a mutual agreement in a meeting session of the DRPD. ${ }^{65}$ If the discussion fails to yield mutual agreement, voting then may commence. ${ }^{66}$

Similar structure is then implemented even to the village level. This uniform structuring is even regulated more strictly under Law Number 6 of 2014 Concerning Village (the Village Law), despite the organization of village is supposed to be based on: a) recognition; b) subsidiary; c) diversity; d) togetherness; e) cooperation; f) kinship; g) reconciliation; h) democracy; i) independence; j) participation; k) equality; I) empowerment; and $\mathrm{m}$ ) sustainability. ${ }^{67}$ There are several things for the government to observe in order to instruct the legal policy of a village, which are village affairs, organizational structure, and the mechanism of deliberative democracy.

Firstly, regarding village affairs, village government is defined as the implementation of government affairs and local community interests under the system of the Republic of Indonesia, ${ }^{68}$ which serves as the primary indication that the political system of the village is being synchronized with that of the central government. The legal policy is derived into the authority of the village which involves authority on the governmental implementation of the village, development of the village, education of the village residents, and empowerment of the village residents based on their initiatives, rights of origin, and traditions. ${ }^{69}$ Such local initiative, however, faces an obstacle in the government intervention on their system and authority. The government's moves to identify and turn the authority of the village into an inventory ${ }^{70}$ are enough to induce passive attitude from the local residents. This is made worse by the specification of the village

\footnotetext{
63 Ibid., page 15.

${ }^{64}$ Article 67 Law Number 17 of 2014 Concerning MPR, DPR, and DPD, and DPRD.

65 Article 128 verse (1) Law Number 23 of 2014 Concerning Local Government (Local Government Law 2014).

${ }^{66}$ Article 128 verse (2) of Local Government Law 2014.

67 Article 3 of Village Law 2014.

68 Article 1 verse j of Village Law 2014.

69 Article 18 of Village Law 2014.

${ }^{70}$ Article 37 Government Regulation Number 43 of 2014 Concerning Implementing Regulation of law Number 6 of 2014 Concerning Village.
} 
authority per an instruction of the minister. ${ }^{71}$ Thus, innovation, creativity, and initiative of the village have to stay passive, only capable of waiting for any instructions from the higher governmental unit in the municipal level.

Secondly, the organization structure of a village is altered into a formal structure, where the officials are elected by the village residents; ${ }^{72}$ the election is conducted within the scope of municipal at simultaneous occasion. ${ }^{73}$ Another less adaptive aspect of the unification of the system is also evident in the service term of a village head, which is 6 years per period, and could be re-elected for 3 periods, either consecutively or not consecutively. ${ }^{74}$ This 'fever' of formalization on the village organizational system has the potential of raising a dispute regarding the result of village head election. If there indeed is a dispute regarding the election result of regent, ${ }^{75}$ regent is obliged to settle the dispute. ${ }^{76}$ Apart from the village head, the formalization unfortunately also affects the Village Consultative Body (BPD) which is a representative body whose membership appointment used to be done in deliberative democracy's way. ${ }^{77}$ Formulation of legislation and regional regulation are symmetrically set in line with the village regulations that was done by the village head after consulting the BPD. ${ }^{78}$

Thirdly, it is regarding the method of carrying out deliberative democracy in the village. In Article 54 (1), it is regulated that, "Village reconciliation is a deliberative forum consisting of the BPD, village government, and elements of village residents to discuss strategic issues regarding village government". Strategic issues in this context include village structuring, establishment of village-owned enterprise, inventorial of village assets, investment plan for the village, or extraordinary occasion that calls for a meeting. The village discussion is also done to replace the village head who happens to be terminated from their term due to special circumstances. ${ }^{79}$ The notion of prioritizing mutual agreement before resorting to voting serves a good element to invigorate the deliberative democracy. However, such notion is reduced by the stipulation regarding discussion quorum as well as other strictly formal stipulations that are familiar with the system of the DPR/DPRD. ${ }^{80}$ Such regulation seems unsuitable for a meeting of village head and BPD that is normally attended only by six to nine people.

\footnotetext{
71 Minister of Village, Developing Under Develop Region, and Transmigration Regulation Number 1 of 2015 Concerning the Authority Guideline based on Original Rights and Local Authority on Village Scale.

72 Article 34 verse (1) of Village Law 2014.

73 Article 31 verse (1) of Village Law 2014.

${ }^{74}$ Article 39 of Village Law 2014.

75 Article 37 verse (5) of Village Law 2014.

76 Article 37 verse (6) of Village Law 2014.

77 Article 56 verse (1) of Village Law 2014.

78 Article 1 number 7 of Village Law 2014.

79 Article 47of Village Law 2014.

${ }^{80}$ Article 65 of Village Law 2014.
} 
It is mentioned that the state should be careful in implementing legal policy on the performance of village government, since it has the potential of disrupting the harmony of culture and tradition. In Bali, for example, the regents and mayors are very careful in determining to register an office village or traditional village to conform with the instruction the Village Law. ${ }^{81}$ This is because of the conflicting definitions of traditional village in the Village Law and the pakraman (traditional villages) in Bali. Pakraman in Bali still relies on traditional law. Its law is regulated by autonomous Hindu structure. ${ }^{82}$ There is also a dualism of structure in the organization of traditional village, between a traditional leader and an actual official village head. Because of that, problems tend to arise as identified by Purbathin Hadi in regard to the autonomy and democratization of traditional village. The problems include:

"(1) Dualism of village governments; (2) The vague structural relationship between regency and traditional village; (3) dualism of law due to the recognition of traditional village as a legal entity; (4) Risk of conflict between villages regarding territorial border, where careless government intervention may only escalate the conflict; (5) formalization of awig-awig (traditional rules or law) that is facilitated by the government through a strict format which reduces Balinese society into a homogeneous one; and (6) the utilization of Pecalang (traditional peacekeepers) for economic and political purposes." 83

Thus, the implementation of the village law enforces a structuring of uniform village governments. Such condition has the potential of breeding disputes. ${ }^{84}$ In improving the notion of deliberative democracy itself, Yudi Latif asserts that a political decision is considered proper only if it conforms to four conditions, which are: 1) based on equality and rationality; 2) dedicated for common good; 3) being future oriented, possessing no transactional property that is destructive; and 4) impartiality of which includes the considerations of all parties involved. ${ }^{85}$

\section{Conclusion}

Discourse on deliberative democracy is derived as a legal policy to see whether there is a design for the direction towards which the democratic process that village

\footnotetext{
81 Mutia Ramadhani and Indah Wulandari, "Pemimpin Masyarakat Bali Sepakat Tunda Pendaftaran Desa ke Pusat", http://nasional.republika.co.id/berita/nasional/umum/15/01/13/ni4asa-pemimpin-mas yarakat-bali-sepakattunda-pendaftaran-desa-ke-pusat, accessed on 13 Januari 2015.

82 Ibid.

83 Agus Purbathin Hadi, “Eksistensi Desa Adat dan Kelembagaan Lokal: Kasus Bali”, http://suniscome.50webs.com/ data/download/35\%20DESA\%20ADAT\%20BALI.pdf, accessed on 5 November 2015, accessed on 5 November 2015, page 3-4.

${ }^{84}$ Article 24 of Cirebon Local Government Act Number 6 of 2010 Concering the Election, Appointment and Discharge of Kuwu.

85 Yudi Latif, Negara..., Op.cit., page 478.
} 
is heading. It is apparent that there has been a reversed paradigm in the adoption of systems from village-MPR to MPR-village. Such change seems contradictive with the concept of deliberative democracy upheld by the founding fathers of Indonesia. Observing this reversed pattern, it is no surprise that Bagir Manan states that Indonesia's current democracy suffers limitation in regards of the aspects of freedom and openness. ${ }^{86}$ In an even larger scope, Indonesian democracy is still limited as a mechanism of power: of attaining it, performing it, defending it, or influencing it. ${ }^{87}$

The notion of deliberative democracy is only realized in the realm of ruling elite or social elite. Such reality forces the authorized party that holds political superstructure and infrastructure to pay close attention to the dynamics of the policy. ${ }^{88}$ Even if there is indeed a carefully designed legal policy, it is still worrying that the most appropriate model towards which design to be achieved is still yet to be decided. Unfortunately, the interpretation of democracy as a mere battle over power regime has been massively widespread onto the bottom-most level of the government-the village. Bagir Manan expresses skepticism on the current system of democracy, that it might slide down into anarchy due to the incompetence of the government. ${ }^{89}$

To mend the mistake of such implementation of democracy, Bagir Manan puts four factors that can improve the prospect of democracy in Indonesia. First, democracy has to be placed as a system inseparable from the notion of State of Law and Human Rights. ${ }^{90}$ Secondly, democracy is performed with responsibility and is dedicated only for the common good, not for the interest of a power holder or majority or a particular faction. ${ }^{91}$ Thirdly, democracy has to abide to the obligation of preserving harmony and social values, which also means that it has to uphold the ethics and law above all. ${ }^{92}$ Without conforming to these three factors, democracy will only result in prejudice and manipulation. In facing it, Bagir Manan emphasizes on two choices for the people: to hesitantly participate or to put an end to the misguided democracy with their own hands. ${ }^{93}$ Fourthly, the need for an intellectual responsibility that is not only nurtured in intelligence, but also in great affection for the unfortunate; whose sole interest is not to enjoy the perks and luxury of power. ${ }^{94}$

\footnotetext{
86 Bagir Manan, Politik Publik..., Op.cit., page 30.

87 lbid., page 30-31.

88 Ibid., page 35-36.

89 Ibid., page 32 .

90 Ibid.

91 Ibid., page 33.

92 Ibid.

93 Ibid., page 34.

94 Ibid., page 36.
} 
A communal principle creates a just government that is performed with responsibility for the utmost interest of Indonesian democracy that includes political and economic democracy. ${ }^{95}$ Under the influence of faith, humanitarianism, unity, and democracy, Indonesia will walk upon a foundation of righteousness, justice, good, honesty, and purity. The basic principle of the One and Almighty God will truly be realized and democracy will truly be practiced, a democracy that is free from corruption and anarchy, both of which, according to Hatta, are dangers that always haunt democracy, and threaten to destroy its pillars if not addressed..$^{96}$ Nevertheless, this article only serves as a preliminary work where weaknesses can be found in its analysis. It is why it requires a further, more in-depth and comprehensive research on the issue of deliberative democracy in Indonesia.

\section{Daftar Pustaka}

\section{Buku}

Abdul Latif dan Hasbi Ali, Politik Hukum, Sinar Grafika, Jakarta, 2010.

Abu Daud Busroh dan Abu Bakar Busroh, Asas-Asas Hukum Tata Negara, Ghalia Indonesia, Jakarta, 1983.

Aidul Fitriciada, Rekonstruksi Tradisi Bernegara Dalam UUD 1945, Genta Publishing, Bantul, 2014.

Alexander, P.C., Perils of Demokrasi, So Maiya Publication, New Delhi, 1995.

Bagir Manan, DPR, DPR, dan MPR dalam UUD 1945 Baru, FH UII Press, Yogyakarta, 2003.

, Lembaga Kepresidenan, Cetakan ke-2, FH UII Press, Jakarta, 2003. , Politik Publik Pers, Dewan Pers, Jakarta, 2012.

B. Arief Sidharta, dkk (Ed.), Butir-Butir Gagasan tentang Hukum dan Pemerintahan yang Layak, Citra Aditya Bakti, Bandung, 1996.

David Held, Models of Democracy, Third Edition, Polity Press, Cambridge, 2006.

Eddy Purnama, Kedaulatan Rakyat, Nusamedia, Bandung, 2007.

Friedmann, Wolfgang, Legal Theory, Steven Sons, London, 1976.

Imam Syaukani, Dasar-Dasar Politik Hukum, Raja Grafindo Persada, Jakarta, 2010.

Jimly Asshiddiqie, Pengantar IImu Hukum Tata Negara, Jilid II, Sekretariat Jenderal

dan Kepaniteraan Mahkamah Konstitusi Republik Indonesia, Jakarta, 2006.

Khalid O. Santosa, (Ed.), Mohammad Hatta: Demokrasi Kita, Pikiran-Pikiran tentang

Demokrasi dan Kedaulatan Rakyat, Sega Arsy, Bandung, 2009.

Lijphart, Arend, Patterns of Democracy, Yale University Press, Yale, 1999.

\footnotetext{
95 Mohammad Hatta, Bung Hatta Berpidato Bung Hatta Menulis, Jakarta: Mutiara Jakarta, 1979, page 98-99.

96 Ibid., page 101.
} 
Mezey, Michael L., Representatives Democracy, Legislators and Their Constituents, Rowman \& Littlefield Publishers, Inc., Maryland, 2008.

Miriam Budiardjo, Dasar-Dasar Ilmu Politik, cetakan kelima belas, PT. Gramedia Pustaka Utama, Jakarta, 1993.

Mohammad Hatta, Bung Hatta Berpidato Bung Hatta Menulis, Mutiara Jakarta, Jakarta, 1979.

RM A.B. Kusuma, Lahirnya Undang-Undang Dasar 1945, Badan Penerbit Fakultas Hukum Universitas Indonesia, Jakarta, 2009.

Sri Soemantri, Padmo Wahjono (Ed.), Masalah Ketatanegaraan Indonesia Dewasa Ini, Ghalia Indonesia, Jakarta, 1984.

Yudi Latif, Negara Paripurna, Historisitas, Rasionalitas, dan Aktualitas Pancasila, Kompas Gramedia, Jakarta, 2011.

\section{Dokumen Lain}

Agus Purbathin Hadi, "Eksistensi Desa Adat Dan Kelembagaan Lokal: Kasus Bali", Yayasan Agribisnis/Pusat Pengembangan Masyarakat Agrikarya (PPMA), hlm. 34, http://suniscome.50webs.com/data/download/35\%20DESA\% 20ADAT\%20BALI.pdf, accessed on 5 November 2015.

Asmara Nababan (Ed.), Satu Dekade Reformasi: Maju dan Mundurnya Demokrasi di Indonesia. Ringkasan Eksekutif dan Laporan Awal Survei Nasional Kedua Masalah dan Pilihan Demokrasi di Indonesia (2007 - 2008), Demos-Lembaga Kajian Demokrasi dan Hak Asasi.

Bagir Manan, "Politik Hukum Untuk Otonomi Daerah", Kuliah Umum Pasca Sarjana Fakultas Hukum Universitas Syiah Kuala, Banda Aceh, 26September 2013.

H. Gayatri, "Demokrasi Lokal Di Desa", http://interseksi.org/publications/essays/ articles/demokrasi_lokal_di_desa.html, accessed on 5 November 2015.

I Gede Pantja Astawa, "Hak Angket Dalam Sistem Ketatanegaraan Indonesia Menurut UUD 1945", Tesis Universitas Padjadjaran, Bandung, 1999.

Mutia Ramadhani and Indah Wulandari, "Pemimpin Masyarakat Bali Sepakat Tunda Pendaftaran Desa ke Pusat", http://nasional.republika.co.id/berita/nasional/ umum/15/01/13/ni4asa-pemimpin-masyarakat-bali-sepakat-tundapendaftaran-desa-ke-pusat, accessed on 13 January 2015. 
619 PADJADJARAN Jurnal Ilmu Hukum, Volume 2 Nomor 3 Tahun 2015

\section{Dokumen Hukum}

The Amandment of 1945 Constitution.

Law Number 42 of 2014 Concerning MPR, DPR, DPD, and DPRD.

Law Number 23 of 2014 Concerning Local Government.

Law Number 6 of 2014 Concerning Village.

Government Regulation Number 43 of 2014 Concerning Implementing Regulation of Law Number 6 of 2014.

Minister of Village, Developing Under Develop Region, and Transmigration Regulation Number 1 of 2015 Concerning the Authority Guideline based on Original Rights and Local Authority on Village Scale.

Cirebon Local Government Act Number 6 of 2010 Concering the Election, Appointment and Discharge of Kuwu. 